The

Anthony Hecht Lectures in the Humanities 
This page intentionally left blank 


\section{TRUE FRIENDSHIP}

Geoffrey Hill, Anthony Hecht, and Robert Lowell Under the Sign of Eliot and Pound

\section{Christopher Ricks}

Yale University Press - New Haven \& London 
This book was first presented as the Anthony Hecht Lectures in the Humanities given by Christopher Ricks at Bard College in 2007. The lectures have been revised for publication.

Copyright (C) 2010 by Christopher Ricks.

All rights reserved.

This book may not be reproduced, in whole or in part, including illustrations, in any form (beyond that copying permitted by Sections 107 and 108 of the U.S. Copyright Law and except by reviewers for the public press), without written permission from the publishers.

Designed by Lindsey Joy Voskowsky.

Set in Bembo type by Tseng Information Systems, Inc.

Printed in the United States of America.

Library of Congress Cataloging-in-Publication Data Ricks, Christopher B.

True friendship : Geoffrey Hill, Anthony Hecht, and Robert Lowell under the sign of Eliot and Pound / Christopher Ricks.

p. cm. - (The Anthony Hecht lectures in the humanities)

"This book was first presented as the Anthony Hecht Lectures in the Humanities given by Christopher Ricks at Bard College in 2007.

The lectures have been revised for publication."

Includes bibliographical references and index. ISBN 978-0-300-13429-2 (alk. paper)

1. Hill, Geoffrey - Friends and associates. 2. Hecht, Anthony, 1923-2004Friends and associates. 3. Lowell, Robert, 1917-1977-Friends and associates.

4. Eliot, T. S. (Thomas Stearns), 1888-1965-Influence. 5. Pound, Ezra, 1885-1972-Influence. 6. American poetry-2oth century-History and criticism. 7. English poetry-2oth century-History and criticism. I. Title.

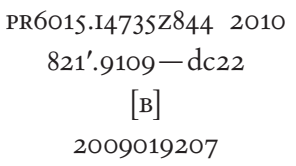

A catalogue record for this book is available from the British Library.

This paper meets the requirements of ANSI/NISO Z39.48-1992

(PERMANENCE OF PAPER).

$\begin{array}{llllllllll}10 & 9 & 8 & 7 & 6 & 5 & 4 & 3 & 2 & 1\end{array}$ 
The Anthony Hecht Lectures in the Humanities, given biennially at Bard College, were established to honor the memory of this preeminent American poet by reflecting his lifelong interest in literature, music, the visual arts, and cultural history. Through his poems, scholarship, and teaching, Anthony Hecht has become recognized as one of the moral voices of his generation, and his works have had a profound effect on contemporary American poetry. The books in this series will keep alive the spirit of his work and life. 
This page intentionally left blank 